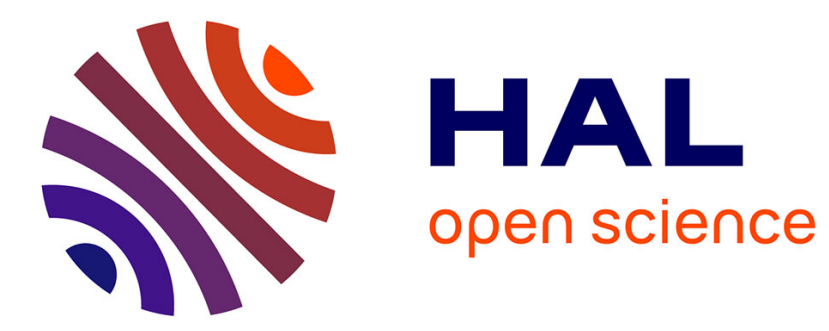

\title{
Exploring the in situ high temperature emissivity of 2014-2015 Bardarbunga magmas
}

Jonas Biren, Lionel Cosson, Leire del Campo, Cécile Genevois, Emmanuel Veron, Sandra Ory, Hao Li, Aneta Slodczyk, Joan Andújar

\section{To cite this version:}

Jonas Biren, Lionel Cosson, Leire del Campo, Cécile Genevois, Emmanuel Veron, et al.. Exploring the in situ high temperature emissivity of 2014-2015 Bardarbunga magmas. vEGU21: Gather Online, Apr 2021, Online, France. 10.5194/egusphere-egu21-714 . hal-03554570

\author{
HAL Id: hal-03554570 \\ https://hal.science/hal-03554570
}

Submitted on 3 Feb 2022

HAL is a multi-disciplinary open access archive for the deposit and dissemination of scientific research documents, whether they are published or not. The documents may come from teaching and research institutions in France or abroad, or from public or private research centers.
L'archive ouverte pluridisciplinaire HAL, est destinée au dépôt et à la diffusion de documents scientifiques de niveau recherche, publiés ou non, émanant des établissements d'enseignement et de recherche français ou étrangers, des laboratoires publics ou privés. 
EGU21-714

https://doi.org/10.5194/egusphere-egu21-714

EGU General Assembly 2021

(c) Author(s) 2022. This work is distributed under

the Creative Commons Attribution 4.0 License.

\title{
Exploring the in situ high temperature emissivity of 2014-2015 Bardarbunga magmas
}

\author{
Jonas Biren ${ }^{1}$, Lionel Cosson ${ }^{2}$, Leire del Campo ${ }^{2}$, Cécile Genevois ${ }^{2}$, Emmanuel Veron ${ }^{2}$, Sandra Ory², \\ Hao Li ${ }^{1}$, Aneta Slodczyk ${ }^{1,2}$, and Joan Andújar ${ }^{1}$ \\ ${ }^{1}$ ISTO, UMR 7327, CNRS-Université d'Orléans-BRGM, 45071 Orléans, France (jonas.biren@cnrs-orleans.fr) \\ ${ }^{2} \mathrm{CEMHTI}$, UPR 3079, CNRS-Université d'Orléans, 45071 Orléans, France
}

\begin{abstract}
Temperature is a key parameter controlling the rheology of lava flows. Unfortunately, the hazardous behavior of eruptions prevents direct measurements of hot magmatic bodies. Hence, the temperature of magma is mostly retrieved by using remote sensing methods (groundbased or satellite-based detectors) build on measuring the infrared (IR) radiance of the body [1]. These well-established techniques are however subjected to important errors related to, among others, the poor knowledge of the spectral emissivity $(\varepsilon)$, which is one of the most critical parameters in IR radiance measurement $[2,3]$. In this study, we performed in situ optical measurements at relevant magmatic temperatures of basaltic magma from the 2014-2015 Holuhraun eruption (Bardarbunga volcano, Iceland). Spectral emissivity has been systematically determined over a wide spectral range $\left(400-15000 \mathrm{~cm}^{-1}\right)$ covering TIR, MIR and SWIR regions, from room temperature up to $1473 \mathrm{~K}$ using a non-contact in situ IR emissivity apparatus [4]. SEM, EMPA, Raman spectroscopy, DSC, XRD and TEM techniques helped characterize and understand the complex radiative behavior of this natural magmatic composition. The results show not only that spectral emissivity varies accordingly with temperature and wavenumber but also that small changes in bulk rock composition or texture produce drastic changes in emissivity at given temperature, with iron content and its oxidation state being the main agents controlling this parameter. Appropriate emissivity values can then be used to refine current radiative data from IR remote sensing and to implement the thermo-rheological models of lava flows [5] as to support hazard assessment and risk mitigation.
\end{abstract}

References: [1] Kolzenburg et al. 2017. Bull. Volc. 79:45. [2] Harris, A. 2013: Cambridge University press. 728. [3] Rogic et al. 2019 Remote Sens., 11, 662 [4] De Sousa Meneses et al. 2015. Infrared Physics \& Technology 69. [5] Ramsey et al. 2019. Annals of Geophysics, 62, 2.

Keywords: Spectral emissivity, temperature, IR spectroscopy, remote sensing, basalt 